\title{
ACQUISITION OF DIMINUTIVES
}

IN TYPOLOGICALLY DIFFERENT LANGUAGES: EVIDENCE FROM RUSSIAN AND ESTONIAN

\author{
Victoria V. Kazakovskaya, Reili Argus
}

\begin{abstract}
The comparative paper considers diminutives at the early stages of development based on the longitudinal data of typicallydeveloping monolingual children, aged up to three years old, acquiring languages which are different in terms of diminutive systems, i.e. rich (in Russian) and poor (in Estonian). The impact of such factors as word formation and inflectional productivity, transparency, input frequency and semantic diversity on the acquisition of diminutives is discussed. From these factors, word formation and inflectional productivity are considered to have the most evident impact on the acquisition of diminutives in both languages. Being a powerful trigger for the development of early derivation and morphology, diminutives are prominent at the beginning of the acquisition of derivation in Estonian as the only derivation category, whereas they develop constantly alongside other derivatives in Russian.
\end{abstract}

Keywords: derivation, nouns, word formation, diminutives, suffixes, first language acquisition, child speech, child-directed speech, Estonian, Russian

\section{Introduction}

Diminutive suffixes are among the first morphemes children acquire. Dressler and Merlini Barbaresi (1994) claim that diminutives are acquired early because they belong to non-prototypical derivation morphology: i.e., they are located between derivation and inflection. At the same time, diminutives are important in a child-centered situation from a pragmatic point of view, since their function is the creation of a familiar, personal world due to their meanings of smallness and endearment. However, while diminutive-rich languages (like Lithuanian, Russian, or Croatian) are described concerning some facets of their acquisition (specifically, 
the influence of the use of diminutives in child-directed speech (CDS, input) on the speed and ease of a child's acquisition of case, number, and gender was shown (Savickienè, Dressler 2007)), little attention has been paid to languages which have only a restricted number of diminutives and consequently diminutive suffixes (like English, French or Turkish). That is why we compare Russian and Estonian not only as two typologically different languages (Indo-European, inflectional vs. Finno-Ugric, mostly agglutinating), but also as good examples of different diminutive systems: diminutive-rich vs. diminutive-poor. Since typological features of languages are acquired by children early (Slobin 2006), we could therefore suppose that diminutive systems in the languages under investigation will be acquired differently. It should be mentioned that selected features of diminutive acquisition in Russian have repeatedly attracted attention (Olmsted 1994, Kempe et al. 2003, Protassova, Voeikova 2007 among others), whereas the acquisition of diminutives in Estonian has been briefly described only in one comparison with a typologically close language, Finnish (Argus, Laalo 2020).

Another disputed issue is the question of influence on the acquisition of diminutives of not only the typological characteristics of the language, but also CDS. The fact is that since the pioneering works of Ferguson (e.g. 1977) it has been known that diminutives are one of the prominent features of CDS. However, input is characterized by great variability, depending on the individual type of caregivers, socioeconomic status (SES), the nationality of the families etc. (Bornstein, Bradley 2003, Rowe 2008 among others). One could also surmise that the gender of a child may also be important (Berko Gleason et al. 1990). In turn, it has been argued (Haman 2003: 16) that no particular type of changes in the frequency of diminutives in CDS are likely to lead to changes in the usage of diminutives in child speech (CS, output).

We will begin this paper with a brief overview of the target system of diminutives in Russian and Estonian (§1.1) and by setting the main research questions (\$1.2), thereafter describing our data and methodology (\$2) and presenting the results of our study of diminutive acquisition, alongside their discussion (\$3). That is, the development of diminutives will be discussed, starting with an analysis of diminutives among all nouns and nominal derivatives in CS and CDS (\$3.1), followed by a description of the emergence of diminutive suffixes (\$3.2). Diminutives in the course of development, their productivity and semantic features and the input-output relationship will be analysed afterwards $(\$ \S 3.3-3.6)$. The paper will conclude with some final remarks concerning the impact of different factors on the acquisition of diminutives in both languages (\$4).

\subsection{Diminutive systems in Russian and Estonian: similarities and differences}

Russian, being a morphemically-rich inflectional East Slavic language, has quite a complex system of affixes, including diminutive suffixes (Švedova 2005). The Russian derivation system has more than 30 diminutive morphemes and their allomorphs in nouns (and prototypical diminutives are nouns, see some examples below), apart from being used in adjectives (xoroš-en'k(ij) ${ }^{1}$ 'good-DIM'), verbs

Hereafter in Russian data the sign " $(. .$.$) " is used for marking the endings of most feminine and neuter nouns and$ adjectives to distinguish them from suffixes as well as the infinitive suffix $-t^{\prime}(-t i)$ in verbs. Most masculine and some feminine nominative singular endings are zero (Ø). 
(baj-uška(t') 'sleep (BT word)-DIM'), and even uninflected words like adverbs (xoroš-en'k-o 'well-DIM-SUF') or interjections ( $a j$-uški 'ah-DIM'). Diminutives are frequent in modern Russian (Fufaeva 2017, Voeikova 2020 among others). In contrast to Russian, there are ten times fewer such suffixes in Estonian, where diminutives are not frequent in colloquial speech (Kasik 2015).

Due to their transparency, Russian diminutive suffixes prove to be productive and frequent within derivation. However, their word formation productivity has a different degree and along with it, respectively, a different frequency. The repertoire of Russian productive diminutive suffixes includes the following:

a) e.g. -ik (dom 'house' $\rightarrow$ dom-ik 'house-DIM'), -ok/-ek (grib 'mushroom' $\rightarrow$ grib-ok 'mushroom-DIM'), -čik (stul 'chair' $\rightarrow$ stul'-čik 'chair-DIM'), -išk (syn 'son' $\rightarrow$ syn-išk $(a)$ 'son-DIM'); these suffixes are used mostly within word formation from masculine nouns;

b) e.g. -ičk, -očk/-ečk (mam(a) 'mommy' $\rightarrow$ mam-očk(a) 'mommy-DIM'), -on'k/-en'k (babulj(a) 'granny' $\rightarrow$ babul-en'k(a) 'granny-DIM'), -ušk (lis(a) 'fox' $\rightarrow$ lis-ušk (a) 'fox-DIM'), -uš, used mostly for derivation from feminine nouns;

c) e.g. -yšk ( $\operatorname{soln}-c(e)$ 'sun' $\rightarrow$ soln-yšk(o) 'sun-DIM'), -ušk (mor(e) 'sea' $\rightarrow$ morj-ušk (o) 'sea-DIM', -c (zerkal(o) 'mirror' $\rightarrow$ zerkal'-c(e) 'mirror-DIM') used mostly within word formation from neuter nouns.

Such suffixes as -urk (doč 'daughter' $\rightarrow$ doč-urk (a) 'daughter-DIM'), -onk

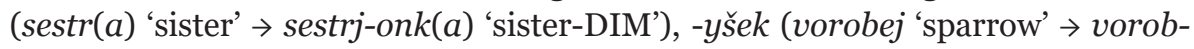

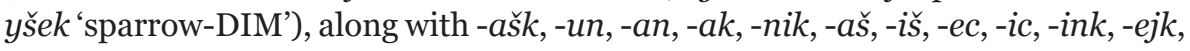
-onok, -unj, -at, -anek are less or non-productive in modern Russian.

Some suffixes (both productive and non- or less productive) are used within derivation from nouns of two genders. For example, $-k$ is used with both feminines ( $m y$ š 'mouse' $\rightarrow$ myš- $k(a)$ 'mouse-DIM') and neuters ( $\operatorname{molok}(o)$ 'milk' $\rightarrow$ moloč- $k(o)$ 'milk-DIM'), the suffixes -usj and -ulj are used with both feminines (bab(a) 'grandmother' $\rightarrow$ bab-usj( $a$ ), bab-ulj( $a$ ) 'grandmother-DIM') and masculines (ded 'grandfather' $\rightarrow \operatorname{ded}-u s j(a)$, ded-ulj(a) 'grandfather-DIM').

In Estonian the list of diminutive suffixes is restricted to three: $-u\left(n u k k^{\text {'doll' }} \rightarrow\right.$ $n u k-u$ 'doll-DIM'), $-k e$ ( $k a l a$ 'fish' $\rightarrow$ kala-ke 'fish-DIM') and -kene (hiir 'mouse' $\rightarrow$ hiire-kene 'mouse-DIM'). The latter is a suffix consisting of two suffixes (-ke and $-n e$ ) in nominative and can be called a stronger diminutive, primarily because of its amplifying characteristic.

Despite the different repertoire of diminutive morphemes in both the languages under investigation, the mechanism of diminutivisation is similar "stem+DIM suffix(es)+ending": mjač+ik-ø 'ball+DIM-MASC.NOM/ACC.SG', soln+yšk-o 'sun+DIM-NEUT.NOM/ACC.SG' (RUS) or kassi+ke 'cat+DIM', kassi+kese-le 'cat+DIM.GEN-ALL' (EST). In general, the diminutive pattern, including its linguistic elements (viz. diminutive suffixes), is transparent both morphophonotactically and semantically ${ }^{2}$. However, some stem modifications occur during diminutivization in the case of the diminutive suffix -u: e.g. käsi 'hand' $\rightarrow$ $k a ̈ t-u$ 'hand-DIM' in Estonian. Some phonetic alternations within stems (e.g. [k//č]: $\operatorname{ruk}(a)$ 'hand' $\rightarrow$ ruč-en' $k(a)$ 'hand-DIM') are possible also in Russian. In addition to this, there is significant palatalization in both languages.

\footnotetext{
2 Therefore, the role of transparency could be analysed here only compared with other (non-)transparent nominal
} suffixes, at least for Estonian. 
It should be highlighted that in both languages diminutives are an important tool for the acquisition of morphology ${ }^{3}$. The main reason is that the diminutives (and diminutivisation as a process) shift the noun into a more regular inflectional class. For instance, in Russian the feminines of the $3^{\text {rd }}$ declension class, having a zero ending in NOM and ACC (like doč( $\varnothing$ ) 'daughter'), shift into the $1^{\text {st }}$ declension class with a typical (and regular) for the feminine gender ending - $a$ due to diminutive suffixes: cf. doč- $k(a)$, doč-en'k(a), doč-urk (a) 'daughter-DIM-NOM.SG'. In Estonian the diminutive suffix $-u$ shifts the noun into a more regular inflectional class with no gradation and with a regular and transparent ending $-t$ in partitive case: e.g. käsi : käe : kätt 'hand.NOM' : 'hand.GEN' : 'hand.PARTIT' $\rightarrow$ kät-u : kät-u : kät-u-t 'hand-DIM.NOM' : 'hand-DIM.GEN' : 'hand-DIM-PARTIT'.

Thus, having similar mechanisms of diminutivisation, transparent diminutive patterns and what is called a "usefulness of diminutives" in early acquisition of morphology, Russian and Estonian differ greatly in the size of suffix repertoire (i.e. its richness), the productivity of diminutive suffixes and their predominant usage with nouns of a certain gender.

\subsection{Goals and research questions}

The main goals for our study are to examine a) how different diminutive systems (rich vs. poor, productive vs. non-productive) affect the acquisition of diminutives and derivation in general, b) how early diminutive patterns develop during the course of acquisition, and c) which factors are important for the acquisition of diminutives.

According to the usage-based approaches (e.g. Tomasello 2003), children first acquire the inflections or patterns which are productive and frequent in their input as well as transparent and regular in their language (Dressler 2005, Dressler et al. 2002). However, the target system that children start to acquire differs in the number of such patterns and not all factors have been analysed, even in descriptions of the acquisition of derivation, at least in the two languages under observation. Moreover, results that are inconsistent with usage-based studies, like the impact of transparency, have been obtained. In particular, in Estonian a more transparent system of verb derivation (reflected in CDS) does not have an impact on the first emergence of different derivatives in CS (Argus 2021).

Therefore, the factors of productivity, semantic diversity and input frequency will be analysed in this paper and the following research questions will be addressed:

1. What role does productivity play in the acquisition of diminutives?

2. What role does the semantic diversity of diminutives play?

3. How can input-output relations be described in the acquisition of diminutives? 


\section{Data and method}

Spontaneous longitudinal data (6o hours of audio and video recordings of naturalistic observation, transcribed and coded according to CHILDES methodology (MacWhinney 2000)) from 4 typically-developing monolingual children and their main caregivers (mothers) were studied (see Table 1). Two caregiver-child dyads were taken per language. The children are 2 boys and 2 girls in the second and third years of life, from middle SES families in Russia (Saint Petersburg) and Estonia (Tallinn and Tartu). Although the length of the recordings of Russian children under observation is different, the proportion of noun tokens to all tokens in their CS and CDS is similar (see the last column), which gives us reason to compare their diminutive data.

Table 1. Data analysed

\begin{tabular}{|c|c|c|c|c|c|c|}
\hline Language & $\begin{array}{l}\text { Subject, } \\
\text { gender }\end{array}$ & Age & $\begin{array}{l}\text { Length of } \\
\text { recordings } \\
\text { (hrs) }\end{array}$ & $\begin{array}{c}\text { Total } \\
\text { tokens }\end{array}$ & $\begin{array}{l}\text { Noun } \\
\text { tokens }\end{array}$ & $\begin{array}{c}\% \text { noun } \\
\text { tokens among } \\
\text { all tokens }\end{array}$ \\
\hline \multirow{2}{*}{ Russian } & $\begin{array}{l}\text { Kirill (K.), } \\
\mathrm{m}\end{array}$ & $1 ; 8-3 ; 0$ & 5.4 & $\begin{array}{c}\text { CS } 6247 \\
\text { CDS } 16246\end{array}$ & $\begin{array}{l}\text { CS } 1518 \\
\text { CDS } 3455\end{array}$ & $\begin{array}{l}24.3 \% \\
21.3 \%\end{array}$ \\
\hline & $\begin{array}{l}\text { Liza (L.), } \\
f\end{array}$ & $1 ; 6-3 ; 0$ & 23 & $\begin{array}{l}\text { CS } 15909 \\
\text { CDS } 51102\end{array}$ & $\begin{array}{c}\text { CS } 4335 \\
\text { CDS } 11482\end{array}$ & $\begin{array}{c}26 \% \\
22.5 \%\end{array}$ \\
\hline \multirow{2}{*}{ Estonian } & $\begin{array}{l}\text { Andreas (A.), } \\
m\end{array}$ & $1 ; 7-3 ; 1$ & 15 & $\begin{array}{l}\text { CS } 14131 \\
\text { CDS } 17326\end{array}$ & $\begin{array}{l}\text { CS } 3834 \\
\text { CDS } 3337\end{array}$ & $\begin{array}{c}27 \% \\
19.3 \%\end{array}$ \\
\hline & $\begin{array}{l}\text { Martina (M.), } \\
f\end{array}$ & $1 ; 3-3 ; 0$ & 16.6 & $\begin{array}{l}\text { CS } 14162 \\
\text { CDS } 26416\end{array}$ & $\begin{array}{l}\text { CS } 4302 \\
\text { CDS } 5465\end{array}$ & $\begin{array}{l}30.4 \% \\
20.7 \%\end{array}$ \\
\hline
\end{tabular}

CS and CDS have been analysed according to a) the number (in lemmas and tokens) of diminutives among nouns and nominal derivatives, including the differentiation of new (i.e. first-appearing) lemmas and old (repeating) ones ${ }^{4}$, b) the frequency of diminutives in comparison with other groups of nominal derivatives, $c$ ) the repertoire of diminutive suffixes, d) the different types of productivity of diminutives (an analysis of inflectional productivity has been performed, taking into account the number of types), e) the semantic diversity of diminutives, and f) the input-output relationship within diminutives.

The parameters of productivity and semantic diversity adopted in our study should be briefly explained. To answer the research question concerning the productivity of diminutives we use the following criteria. 1) According to the idea of increasing complexity during acquisition and productive formation of derivatives, the emergence of derivatives compared to non-derived nouns as well as diminutives compared to simplexes/simplicia is analysed. 2) Using different stems with one and the same diminutive suffix, as well as several different derivational suffixes with one and the same stem, one can demonstrate general derivation (word formation) and - more broadly - morphological awareness, including the productive use of diminutive derivation. 3) The occurrence of novel (child-created) diminutives and the development of word formation families including word formation pairs

\footnotetext{
4 Thus, all new derivatives and diminutives were calculated separately from their subsequent repetitions in the
} 
(non-derived noun $\rightarrow$ derived noun) is considered. 4) The emergence of inflectional oppositions in case and number of diminutives and then their mini-paradigms (in comparison with those of other nominal derivatives) is investigated. By semantic diversity of diminutives, we mean the existence of groups within derivatives such as designations of people, objects, animals, birds etc. The analysis of the semantic repertoire of diminutives can provide some evidence not only for the development of early children's lexicon and its main peculiarities in both languages, but also for the main directions of expanding categorization of reality.

\section{Results and their discussion}

\subsection{Diminutives among nouns and nominal derivatives in Russian and Estonian data}

Comparison of diminutives (and - more broadly - derivatives) within the two language corpora shows that the percentage of nominal derivatives (see Table 2, line $a$ ) and diminutives (see line $d$ ) among nouns is higher in the Russian corpora (in lemmas and tokens for both CS and CDS) than in the Estonian data. We can connect these results with the typological differences of these languages: inflectional Russian has more derivatives compared to compounds (Kazakovskaya 2017), whereas more agglutinating Estonian is a mainly compound language, which is mirrored in their acquisition (Argus, Kazakovskaya 2013, 2018).

Table 2. Derivatives and diminutives (DIM) among nouns in CS and CDS (lemmas/tokens)

\begin{tabular}{|c|c|c|c|c|c|}
\hline Line & Feature & RUS (K.) & RUS (L.) & EST (A.) & EST (M.) \\
\hline$a$ & $\begin{array}{l}\text { Derivatives } \\
\text { among nouns, \% }\end{array}$ & $\begin{array}{l}\text { CS 15.5/12 } \\
\text { CDS 26/21 }\end{array}$ & $\begin{array}{l}\text { CS 55/57 } \\
\text { CDS 53/60 }\end{array}$ & $\begin{array}{c}\operatorname{CS} 6.9 / 4.2 \\
\operatorname{CDS} 8.8 / 6.5\end{array}$ & $\begin{array}{c}\text { CS 5.0/4.2 } \\
\text { CDS 11.8/7.2 }\end{array}$ \\
\hline b & $\begin{array}{l}\text { New (first- } \\
\text { appearing) } \\
\text { derivatives, } \\
\text { number/(\%) }\end{array}$ & $\begin{array}{c}\text { CS } 70(78 \%) / \\
131(74 \%) \\
\text { CDS } 242(63.5 \%) / \\
414(56.5 \%)\end{array}$ & \begin{tabular}{|c|} 
CS $524(57 \%) /$ \\
$1152(47 \%)$ \\
CDS $710(41.5 \%) /$ \\
$2184(32 \%)$
\end{tabular} & $\begin{array}{c}\text { CS } 57(96 \%) / \\
79(69 \%) \\
\text { CDS } 90(94 \%) / \\
151(61 \%)\end{array}$ & $\begin{array}{c}\text { CS } 45(92 \%) / \\
123(67 \%) \\
\text { CDS } 135(90 \%) / \\
398(48 \%)\end{array}$ \\
\hline c & $\begin{array}{l}\text { DIM among } \\
\text { derivatives, \% }\end{array}$ & $\begin{array}{l}\text { CS } 18 / 26 \\
\text { CDS 29/30 }\end{array}$ & $\begin{array}{l}\text { CS 68/63 } \\
\text { CDS 57/44 }\end{array}$ & $\begin{array}{c}\text { CS 33.3/14.9 } \\
\text { CDS 19.1/18.1 }\end{array}$ & $\begin{array}{c}\text { CS } 36 / 40.9 \\
\text { CDS } 18.4 / 34.8\end{array}$ \\
\hline$d$ & $\begin{array}{l}\text { DIM among } \\
\text { nouns, } \%\end{array}$ & $\begin{array}{l}\text { CS } 2.8 / 3.2 \\
\text { CDS } 8 / 6\end{array}$ & $\begin{array}{l}\text { CS } 37 / 36 \\
\text { CDS } 30 / 26 \\
\end{array}$ & $\begin{array}{l}\operatorname{CS} 2.3 / 1.0 \\
\operatorname{CDS} 1.7 / 1.2 \\
\end{array}$ & $\begin{array}{l}\text { CS 1.8/1.7 } \\
\text { CDS 2.2/2.5 }\end{array}$ \\
\hline e & $\begin{array}{l}\text { New (first- } \\
\text { appearing) DIM, } \\
\text { number/(\%) }\end{array}$ & $\begin{array}{c}\text { CS } 15(94 \%) / \\
44(96 \%) \\
\text { CDS } 79(70.5 \%) / \\
130(60 \%)\end{array}$ & $\begin{array}{c}\text { CS } 288(46 \%) / \\
623(41.5 \%) \\
\text { CDS } 334(34.5 \%) / \\
854(28.5 \%)\end{array}$ & $\begin{array}{c}\text { CS } 19(100 \%) / \\
24(65 \%) \\
\text { CDS } 24(100 \%) / \\
35(78 \%)\end{array}$ & $\begin{array}{c}\text { CS } 16(67 \%) / \\
48(65 \%) \\
\text { CDS } 17(43 \%) / \\
54(39 \%)\end{array}$ \\
\hline
\end{tabular}

The percentage of diminutives among derivatives in Russian CDS is higher than in Estonian CDS for both lemmas and tokens (see line $c$ ), whereas the Estonian children, according to this parameter, are, metaphorically speaking, between the two Russian children. However, the proportion of new derivatives among all derivatives (see line $b$ ) in Estonian is higher than in one Russian corpus (Liza), for CDS and CS (for lemmas and tokens), and for lemmas in Kirill's data. The percentage of 
diminutives among nouns can be approximately ten times larger (see Liza's data) in Russian compared to Estonian CDS (see line $d$ ), while the difference in the percentage of diminutives among derivatives is not so large (see line $c$ ). This means that in Estonian diminutives are more prominent in derivatives than in nouns in general.

Comparison of corpora within each language shows that in the Russian data (for both lemmas and tokens), Kirill has quite a low percentage of diminutives as well as nominal derivatives, whereas Liza's corpus has the biggest number of nominal derivatives and diminutives from all the Russian and Estonian data under observation. Additionally, in Liza's data the proportion of diminutives among nouns is the largest. The percentage of both new nominal derivatives and new diminutives is higher in Kirill's corpus than in Liza's (see lines $b$ and $e$ ). This means that in the mother-Kirill dyad the percentage of repetitions is small.

The differences between the Estonian children are not so prominent and concern only the percentage of lemmas. The percentage of derivatives among nouns is quite small in the data of both children. The percentage of diminutives among derivatives can still be very different in CS, concerning especially the percentage of diminutive tokens. That is, the percentage of diminutives among all nominal derivatives is $40.9 \%$ in Martina's speech, while this percentage in the speech of Andreas is only $14.9 \%$.

Thus, the initial overview of general results shows some differences not only between Russian and Estonian corpora, but also between the two subjects acquiring the same language. In particular, although diminutives account for a considerable percentage of all derivatives, even in diminutive-poor Estonian, they do not form a large proportion among all nouns; in Russian, however, their number in nouns is more prominent. At the same time, there are also individual differences between girls and boys from different language corpora. Particularly, the data of both girls has more diminutives than that of both boys. Our observations correlate with the results obtained in previous studies (Berko Gleason et al. 1990, see also Protassova, Voeikova 2007, Argus, Kazakovskaya 2018).

\subsection{Emergence of diminutives and their first suffixes}

In both languages diminutives belong to the early derivational category in CS, but in Russian they are one of the first alongside stylistic (viz. colloquial) modifications of nouns like dyr-k(a) 'hole' or kartoš-k(a) 'potato', according to the Academic Russian Grammar (Švedova 2005), whereas in Estonian they are the only early derivational category.

The first diminutive suffixes documented in Russian CS are $-k$, -oč $k$ and $-i k$. The two first suffixes (-k and -očk) appear within feminines: leeč- $k(a)$ 'watering canDIM', astr-očk(a) 'aster-DIM' ( $1 ; 8$ L.). The last one, $-i k$, is used with masculines: e.g. taz-ik 'basin-DIM', list-ik 'leaf-DIM' (1;8 L.). The suffix -aš in the diminutive Step-aš( $a$ ) (1 lemma/3 tokens) from the hypocoristic Stjop ( $a$ ) had been documented two months earlier $(1 ; 6 \mathrm{~L} \text {.) })^{5}$. Liza's data is rich in such hypocoristics (their percentage in CS among all nominal derivatives is $7 \%$ for lemmas and $10 \%$ tokens). They

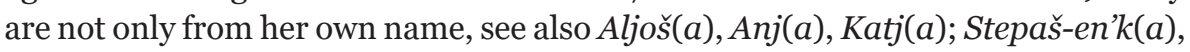

5 Hypocoristics like Liza for Elizaveta (RUS), Atsu for Andreas (EST) were calculated separately from proper 
Marin-očk(a). Kirill's speech, on the contrary, has only a few hypocoristics (Filj(a), Vitalik). The order of emergence of diminutive suffixes in Liza's speech is $-k,-i k$, -očk > -ok, -ek, -čik, -yšk, -ušk, -išk, -ic >-en'k. Kirill begins to use diminutives later than Liza, at 2;3, and his repertoire of suffixes is quite restricted. In his speech, the sequence of emergence of diminutive suffixes is as follows: $-k>-i k$. Thus the early suffixes in the children's diminutives in Russian are productive and frequent and are used with the appropriate noun gender (i.e. according to the target system) but the children under observation differ in the age of emergence of diminutives, the size of the suffix repertoire and the number of hypocoristics.

In Estonian CS the first diminutive suffix is $-u$ (nuk-u 'doll-DIM' (1;3 M.), jänk-u 'bunny-DIM' (1;7 A.)), which is very much lexicalized in colloquial speech. This suffix can be acquired first because it does not make the word longer than two syllables $^{6}$ and shifts the noun to the more regular inflectional class. There are also some hypocoristics, mostly from the child's own name: Andreas $\rightarrow$ Ants-u/Ats-u/ $A t-u$. In all these cases the stem has been modified before the diminutive suffix $-u$ (i.e. according to the target system). The order of emergence of diminutive suffixes in CS is - $u>-k e$ > -kene: nuk-u 'doll-DIM' (1;3 M., 1;8 A.), linnu-ke 'bird-DIM' (1;5 M.), $k o h u-k e^{7}$ 'rise-DIM=sweet cottage cheese' (1;10 A.) > emme-kene 'mommyDIM' (1;9 M.), seene-kene 'mushroom-DIM' (2;7 A.).

Therefore, we can argue that the rich system of Russian diminutives is acquired slightly later than Estonian's much narrower one: $1 ; 6-2 ; 3$ for RUS CS vs. $1 ; 3-1 ; 7$ for EST CS. In the speech of both girls it happens earlier than in the speech of both boys: 1;6 vs. 1;3 for Liza and Martina; 2;3 vs.1;7 for Kirill and Andreas. However, the Russian children use more different diminutive suffixes, which can reach $30 \%$ among all diminutive suffixes in the target system (viz. Liza), and can use several suffixes simultaneously within one month.

\subsection{Diminutives in the course of development}

The percentage of diminutives among nominal derivatives (for lemmas and tokens) increases during development in Russian CS, whereas it decreases in Estonian CS (compare Fig. 1a and $1 \mathrm{~b}$ ).

The Russian children start from 40-60\% of diminutives to all nominal derivatives, while the Estonians start from 100\%. This means that in Estonian all the children's first derivatives are diminutives. Based on this data (see both figures), it can be argued that Estonian children use diminutives mostly at the beginning of the acquisition of derivation. Later, when they have acquired other suffixes, the usage of diminutives does not increase and their percentage among all derivatives even decreases. In turn, in Russian CS, diminutives are one of the groups of early nominal derivatives, which, despite its prevalence, gradually develops along with other derivatives. 


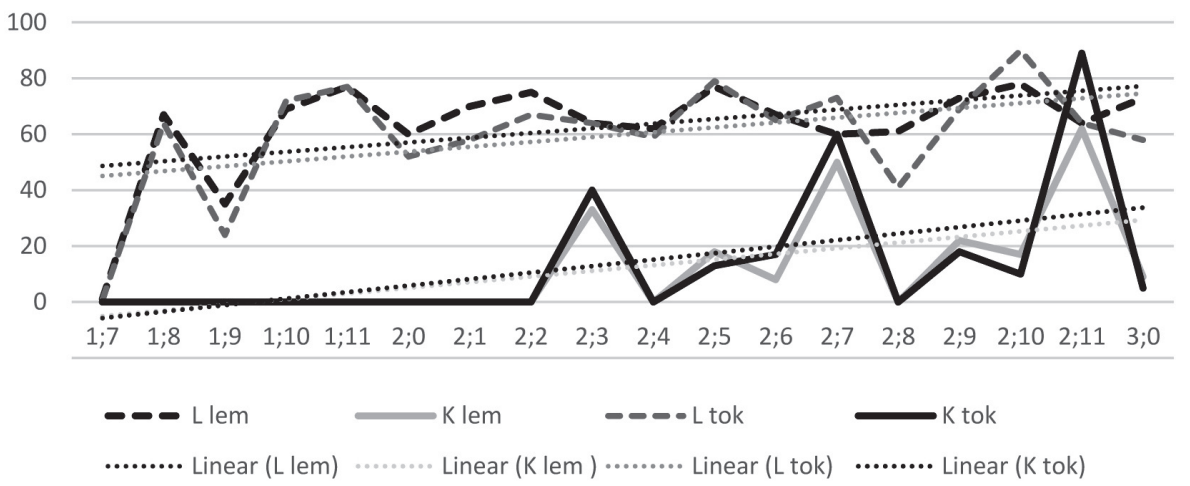

Figure 1a. Development of diminutives in Russian CS (\% among all nominal derivatives)

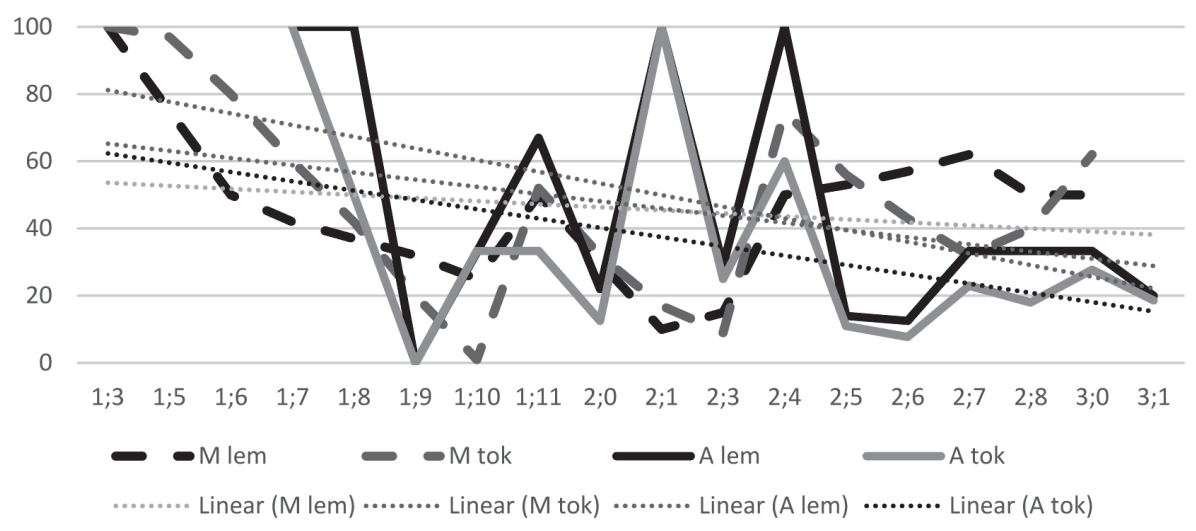

Figure 1b. Development of diminutives in Estonian CS (\% among all nominal derivatives)

\subsection{Productivity of diminutives}

In Russian, the first derived non-diminutive nouns (e.g. krasav-ic(a) 'beauty, belle (woman)' $<$ krasavec 'handsome') emerge at 1;8 in Liza's speech simultaneously with both diminutives and their simplexes like leeč- $k(a)$ 'watering can-DIM' $<$ lej-k(a) 'watering can'. Kirill begins to use the first derived nouns 3 months earlier than diminutives, at 2;0: beg-un 'runner' $\leftarrow$ bega $(t$ ') 'run-INF', prjan-ik 'gingerbread' $\leftarrow$ $\operatorname{prjan}(y j)$ 'gingery, spicy-ADJ', but sporadically and infrequently (2 lemmas / 2 tokens). In Estonian, the first other derived nouns emerged later than diminutives by 2 and 3 months: at 1;5 in Martina's speech (mmeirmut-is [hernehirmut-is] 'scarecrow'), and at 1;10 in Andreas' ( puhk-e+päev 'holiday' $<$ puhka-ma 'rest-INF').

However, in both languages non-diminutive derivative suffixes become productive later than diminutive ones. In Estonian CS, the period between the emergence and the productive usage of non-diminutive suffixes ranged from 6 to 10 months. In Russian, this period is much shorter but differs for both certain semantic groups of derivatives and their productive or non- / less productive suffixes: from o months 
(e.g. -onok for animal babies is used with four stems at 1;9 in Liza's speech: kotj-onok 'baby cat', kozlj-onok 'goatling', myš-onok 'baby mouse', zajč-onok 'leveret') up to 8 months or even more (e.g. the so-called zero suffix for results of activity is used with three different stems at 2;6, 2;9 and 2;11 in Kirill's speech). In both CS the productivity of the suffix of stylistic modifications $-k$ took $1-2$ months.

A comparison of oppositions "simplex vs. diminutives" in the two languages shows that in both the Russian CS, more than half of the diminutives have a pair ( $53 \%$ in Kirill's data, $60 \%$ in Liza's). In turn, within these oppositions, simplexes mostly occur earlier than diminutives (75\% in Kirill's speech, $57 \%$ in Liza's). The percentage of solitary diminutives (those which did not have any simplex matches in CS) is $47 \%$ in Kirill's data and 30\% in Liza's. In both the Estonian CS, simplexes before diminutives occurred in $47 \%$ of instances: approximately $20 \%$ of diminutives were used before simplex, and approximately $30 \%$ of diminutives were solitary.

Russian children can use diminutives productively almost from the beginning. In particular, a diminutive suffix is presented with three different stems at its first appearance in Liza's speech: - $i k$ in taz-ik 'basin-DIM', list-ik 'leaf-DIM', ogurč-ik 'cucumber-DIM' (1;8); all motivating nouns (taz, list, ogurec) are masculine. Kirill's diminutives develop their productivity a bit more slowly: $-i k$ requires 1 month, whereas $-k$ requires 7 months. In his data the productivity of $-i k$ is higher than that of another diminutive suffix, $-k$ : $-i k$ is used with 10 stems, whereas $-k$ is used with 5 stems. Diminutives are the only noun derivation category showing some productivity in Estonian CS, where this process is not so quick, unlike in Russian. Both diminutive suffixes $-u$ and $-k e$ become productive two months after their first emergence: the suffix $-u$ in the speech of Martina, e. g. nuk-u 'doll-DIM' $(1 ; 3)$, jänk-u 'bunny-DIM' (1;5), and the suffix -ke in the speech of Andreas, e. g. kohu$k e$ 'rise-DIM' (sweet cottage cheese) (1;10), tuti-ke 'tuft-DIM' (2;0), while - $u$ in the speech of Andreas and -ke in the speech of Martina takes a little bit more time (3-5 months) to become productive.

Diminutives are like a trigger for the acquisition of derivation, because they are not only the first derivational category to emerge, but also the first members from word formation pairs and families within a nominal pattern " $\mathrm{N} \rightarrow \mathrm{N}$ " including simplexes. In both languages, half (or even more) of word formation families consist of diminutives. In particular, Liza has more than $75 \%$ of word formation pairs and families amongst diminutives. The number of members within word formation families in her speech ranges from 2-3 (list 'leaf' $\rightarrow$ list-ik 'leaf-DIM', list-oč-ek 'leaf-DIM-DIM' $(1 ; 8)$; grib 'mushroom' $\rightarrow$ grib-ok 'mushroom-DIM' $\rightarrow$

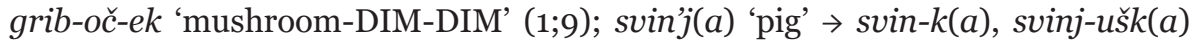
'pig-DIM', svin-in (a) 'pork, the meat of a pig' $(1 ; 9))$ up to seven ( $k o t$ 'cat' $\rightarrow k o t-i k$, $k o t-e n ' k(a)$ 'cat-DIM', kotj-onok 'baby cat', kotjat-k(i) 'baby cat.PL-DIM', koš-k(a) 'female cat', $k o s ̌ e c ̌-k(a)$ 'female cat-DIM' $(1 ; 10)) .53 \%$ of the diminutives in Kirill's speech have a simplex pair, but there are no other pairs besides these. In Estonian, Andreas' data has 7 pairs (of 13 pairs in total) consisting of a diminutive, 2 triples (of 10 in total) and only 5 solitary diminutives. The number of word formation families is larger in Martina's speech. She has 12 pairs (of 28 in total) and 1 triple (of 8 in total) consisting of at least one diminutive, and 4 solitary diminutives. Martina's first word formation families consisting of diminutives are: jänes 'rabbit' $\rightarrow$ 
jänk-u 'bunny-DIM' $\rightarrow$ jänk-u-kas 'bunny-DIM-SUF 'the object having the shape of a bunny'; emme 'mommy' $\rightarrow$ emme-kene 'mommy-DIM'. Andreas' first word formation families are quite similar in the choice of stems: jänk-u 'bunny-DIM' $\rightarrow j a ̈ n-k s u-d$ 'bunny-SUF-PL (bunnies)'; ema 'mother' $\rightarrow$ ema-ke 'mother-DIM'. In addition to word formation productivity, it should be mentioned that based on the transparent diminutive model "masculine N + productive SUF - $i k$ ", the first neologism babbl-ik 'bubble-DIM' occurs almost at the end of the observations in the Russian data (2;9 K.). No novel diminutives were documented in the Estonian corpora.

Analysis of the inflectional productivity of diminutives in comparison with other nominal derivatives shows that in Russian the first derived nouns started to be used productively (i.e. developed the first oppositions in case and/or number) from the beginning in Liza's speech (1 lemma lejk $(a)$ 'watering can' at 1;8), like her first diminutives. However, the number of diminutives having inflectional oppositions is higher (3 lemmas: astr-očk(a) 'aster-DIM', leeč- $k(a)$ ) watering can-DIM', list-ik 'leafDIM'). That is, in the domain of diminutives this is a more intensive process than that of non-diminutives. In addition, one diminutive lemma (ogurč- $i k$ ' cucumber-DIM') has a mini-paradigm, whereas the first mini-paradigms in other derivatives were documented later, at 1;9. In Kirill's speech, the first opposition for one diminutive lemma (dom-ik 'house-DIM') was documented much later, compared to Liza's data, at 2;6, as well as the first mini-paradigms for two derived nouns, one of them is a compound (beton+o+meša-lk(a) 'concrete mixer'), which were noted at 2;5. In Estonian, the number of diminutives having inflectional oppositions is extremely small: there were no inflectional oppositions or mini-paradigms in Martina's speech. The other child, Andreas, had his first opposition of two inflectional forms at 2;8 ( $k$ ohu-ke 'rise-DIM.NOM=cottage cheese' $:$ kohu-kes- $t$ 'rise-DIM-PARTIT') and the first three-member mini-paradigm appeared at 3;1 (kera-ke 'ball-DIM.NOM' : kera-kese 'ball-DIM.GEN' : kera-kese-st 'ball-DIM-ELA'). Only one opposition of two inflectional forms of a non-diminutive derivative is recorded in his data, and no mini-paradigms in other derivatives are documented.

Finally, it should be highlighted that in both languages, diminutive suffixes are more transparent compared to other nominal suffixes, which make them more productive and frequent. For instance, in Estonian some noun derivational suffixes are semantically less transparent than others: e.g. - $i k$ can have a very opaque meaning and denotes just entities, while diminutive suffixes have only diminutive meaning. Thus, diminutives can be acquired early and form mini-paradigms and be members of big word families due to the transparency of their suffixes.

\subsection{Semantic diversity}

In both languages the list of children's diminutives is quite diverse. All Russian and Estonian children start to acquire diminutives with similar semantic categories. These categories are animals and objects which, usually, they are playing with (or eating): e.g. in Russian: ogurč-ik 'cucumber-DIM' (1;8 L.), sovoč-ek 'scoop-DIM' (1;9 L.), myš- $k(a)$ 'mouse-DIM' (2;3 K.); in Estonian: jänk-u 'bunny-DIM' (1;7 A.), linnu-ke 'bird-DIM' (1;5 M.), nuk-u 'doll-DIM' (1;3 M.), lipu-ke 'flag-DIM', tuti-ke 'tuft-DIM' (2;0 A.). 
Diminutives from the name of birds (sinič- $k$ ( $a$ ) 'tit-DIM' ( $2 ; 6$ L.), cypljonoč-ek 'chicken-DIM' (2;10 L.), metsa+linnu-ke 'forest+bird-DIM' (2;4 A.)), people (sestrič$k(a)$ 'sister-DIM' (2;11 L.), ema-ke 'mother-DIM' (3;1 A.)), fictional creatures (drakon-čik 'dragon-DIM' (2;9 L.), monstr-ik 'monster-DIM' (3;0 K.), mehi-ke 'man-DIM' (2;8 A.)) and from the other diminutives, in particular, so-called double diminutives like grib-oč-ek 'mushroom-DIM-DIM' (2;9 L.), syn-oč-ek 'son-DIM$\operatorname{DIM}^{\prime}(2 ; 11$ L.) appear later.

\subsection{Input-output relationship in a development perspective}

In both languages, the children have more diminutives than their caregivers. The frequency of diminutives in CDS has no clear effect on their acquisition in the sense of strong positive correlations between diminutive lemmas and tokens used by children and their caregivers in the course of development. We can only say that there is some relationship between the total number of diminutives in input and the children's output in Russian. That is, Liza's input contains many diminutives, and there are many diminutives in the girl's speech, and, in contrast, Kirill's input is not as rich in diminutives and there are few diminutives in his speech. However, a strong positive correlation has been revealed between the frequency of the semantic categories of nominal derivatives in CDS and CS based on the data of the two Russian boys (one of them being Kirill) and their caregivers (more details in Kazakovskaya 2019, Kazakovskaya, Voeikova 2021). The most frequent categories (according to their percentage of lemmas/tokens among derived nouns) for both adult-child dyads are diminutives, activities and/or their results, instruments, and agents.

In diminutive-rich Liza's data, the proportion of diminutives to all derivative lemmas increases slightly (see Fig. 2a), and it is larger in CS than in CDS. We can also observe two simultaneous peaks in usage of diminutive lemmas by Liza and her mother at 2;2 and 2;5. In diminutive-poor Kirill's corpus, diminutive lemmas increase in CS, but decrease slightly in CDS. Here there are also two peaks, but later, at 2;8 and 2;11. The first peak is sequential, coming slightly later, at 2;7 in Kirill's speech and at 2;8 in input. In both Russian corpora the first peak in the frequency of diminutives occurs 4-5 months after their documentation in CS.

Some input-output relationships in the sphere of the diminutive suffix repertoire were observed. Kirill uses 2 suffixes $(-k,-i k)$ from the 8 suffixes documented in CDS $(-k,-i k,-o k /-e k,-o c ̌ k,-e n ' k,-c ̌ i k,-y s ̌ k,-u s ̌)$, and both those suffixes have a high degree of productivity. Liza, however, uses the majority (77\%) of the suffixes from her input, viz. 10 suffixes $(-k,-i k,-o k /-e k$, -očk, -čik, -yšk, -ušk, -išk, -ic, -en'k) out of her input total of 13 (- $k$, -ik, -ok/-ek, -očk/-ečk, -čik, -yšk, -ušk, -išk, -c, -ic, $-e n^{\prime} k /-i n^{\prime} k,-u s ̌$, -anek). She uses not only highly productive diminutive suffixes, but also less productive ones. Therefore, we can assume that the more diminutive suffixes a mother uses, the more suffixes her child will use.

In the Estonian data, the percentage of diminutive lemmas among derivatives decreases in CS and CDS in the speech of both subjects. In the CDS of Andreas there is a slight increase in the percentage of diminutives. There is some consistency between the percentage of diminutives in CS and CDS in his data, and there are two joint peaks at age 1;11 and 2;1. 


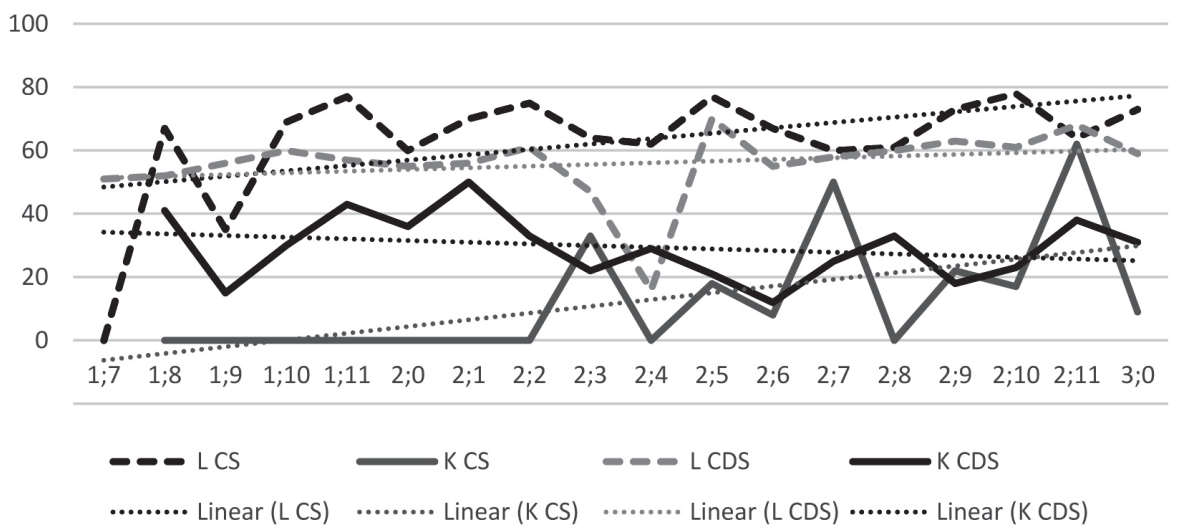

Figure 2a. CDS-CS relationship within diminutives in Russian

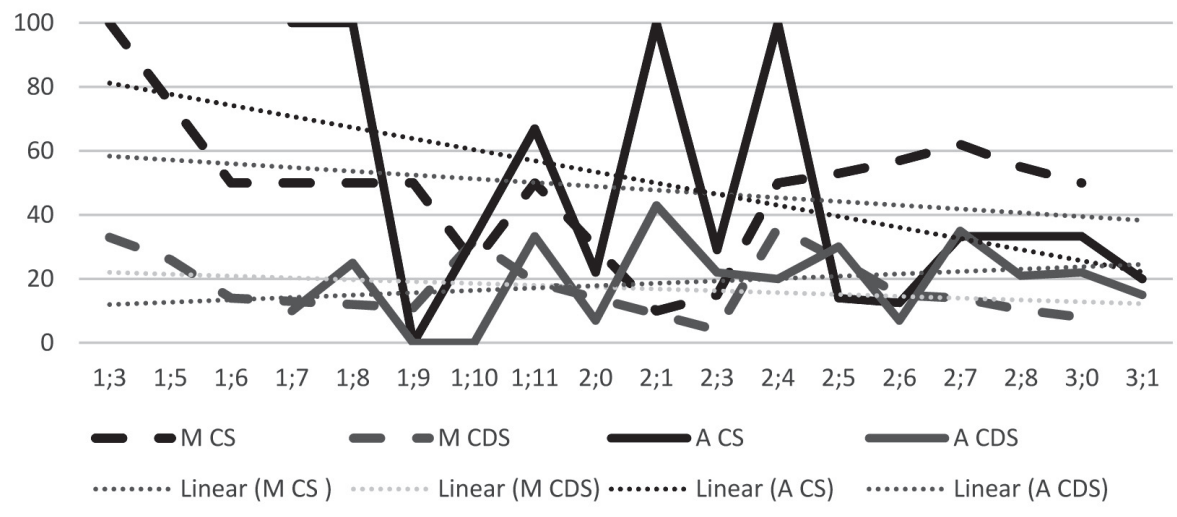

Figure $\mathbf{2 b}$. CDS-CS relationship within diminutives in Estonian

In the Estonian corpus, the repertoire of diminutive suffixes was equal in CS and CDS, that is, all three suffixes were used, both in CS and CDS.

\section{Conclusions}

In both the languages under investigation, diminutives are one of the early derivational categories in CS. The richer system of Russian diminutives starts to be acquired slightly later than the much poorer system of Estonian ones. The proportion of diminutives among nouns and nominal derivatives is higher in Russian, in which it mostly increases during the course of development as opposed to Estonian, where their frequency decreases (for both CS and CDS, in tokens). However, in Estonian there are relatively more new (first-appearing) diminutives among nominal derivatives. This shows that the children's repertoire of diminutives is relatively big. 
Approximately one-third of derivatives in Estonian CS were diminutives and this places the Estonian children between the two (quite different) Russian corpora. On the basis of such differences, one could argue that the different diminutive systems do not much affect the emergence of first diminutives but did affect the number of diminutives among nouns and the general number of diminutives used by the children during the observation period.

Word formation productivity of diminutives in Estonian CS develops soon after the start of their emergence, whereas in Russian CS it can happen from the beginning. In both languages diminutive suffixes are among the productive and transparent ones and this can cause their early productive use. Half (and even more in one of the Russian corpora) of nominal word formation families consist of diminutives. Additionally, the Russian data has occasional diminutives and numerous hypocoristics. The number of oppositions "simplex vs. diminutive" in Russian and Estonian is greater than that of solitary diminutives and also greater than the number of word formation pairs (and - more broadly - families) of non-diminutive derivatives. The same is true for their suffixes, which were also not numerous. For example, in Estonian, many derivative suffixes emerge with only one lemma and this lemma does not emerge with suffixes other than diminutives, usually forming pairs or word formation families.

The repertoire of diminutive suffixes is large in one Russian corpora (Liza's) and restricted to two productive ones in the other corpus (Kirill's); at the same time, both the Russian children acquire the highly productive part of the diminutive repertoire. The suffix repertoire is small in the Estonian data but the children acquire it completely. The semantic features of diminutives (viz. their diversity) are similar for both languages. The children usually first start to use diminutives for animals (or animal figure toys) and objects with which they are playing or eating.

In both languages the children have slightly more diminutives than adults but still no clear impact of CDS on CS was found in terms of positive correlation in the course of development (for both lemmas and tokens). This result is similar to previous results obtained by Haman (2003).

All children use diminutives when getting started with derivation. But in Russian CS the development of diminutives continues constantly alongside other derivational categories such as animal babies, agents, instruments etc. and seems to be a more intensive process than in Estonian, where the diminutives are more like a temporary and early means to acquire derivation. Children start the acquisition of derivation with them, but after one year the number of diminutive tokens starts to decrease (as well as in Estonian CDS) and at the same time the number of other nominal derivatives increases. Hence at the start of acquisition of derivation the diminutives have a prominent role, however, step-by-step, their role somehow decreases.

Thus, the acquisition of diminutives in the two languages is different: the poorer system of diminutives in Estonian emerges slightly earlier than in the much richer system of Russian. Among the factors influencing the acquisition of diminutives, input frequency seems not to have a high importance, while their productivity, transparency and semantics (manifesting the realities of the children's world and a child-centered situation) can be considered to have much greater influence on the acquisition of diminutives and nominal derivation in general. 


\section{Abbreviations}

$\begin{array}{llll}\text { ACC } & \text { accusative case } & \text { INF } & \text { infinitive } \\ \text { ADJ } & \text { adjective } & \text { GEN } & \text { genitive case } \\ \text { BT } & \text { baby talk } & \text { N } & \text { noun } \\ \text { CS } & \text { child speech, output } & \text { NOM } & \text { nominative case } \\ \text { CDS } & \text { child-directed speech, input } & \text { PARTIT } & \text { partitive case } \\ \text { DIM } & \text { diminutive } & \text { RUS } & \text { Russian } \\ \text { ELA } & \text { elative case } & \text { SES } & \text { socioeconomic status } \\ \text { EST } & \text { Estonian } & \text { SUF } & \text { suffix }\end{array}$

\section{References}

Argus, Reili 2008. Eesti keele muutemorfoloogia omandamine ['Acquisition of Inflection in Estonian']. Tallinn University. Dissertations on Humanities 19. Tallinn: TLÜ Kirjastus.

Argus, Reili 2021. Acquisition of derivation in Estonian. - Veronika Mattes, Sabine Sommer-Lolei, Katharina Korecky-Kröll, Wolfgang U. Dressler (Eds.), The Acquisition of Derivational Morphology: A Cross-linguistic Perspective. Language Acquisition and Language Disorders 66. Amsterdam: John Benjamins, 218-236. https://doi. org/10.1075/lald.66.09arg

Argus, Reili; Kazakovskaya, Victoria V. 2013. Acquisition of compounds in Estonian and Russian: Frequency, productivity, transparency and simplicity effect. - Estonian Papers in Applied Linguistics, 9, 23-42. https://doi.org/10.5128/ERYa9.o2

Argus, Reili; Kazakovskaya, Victoria V. 2018. Acquisition of noun derivations in Estonian and Russian. - Estonian Papers in Applied Linguistics, 14, 23-39. https://doi. org/10.5128/ERYa14.02

Argus, Reili; Laalo, Klaus 2020. Linguistic recycling in language acquisition: Child-directed speech and child speech in the study of language acquisition. - AILA Review, 33, 86-103. https://doi.org/10.1075/aila.00o31.laa

Bornstein, Mark H.; Bradley, Robert H. (Eds.) 2003. Socioeconomic Status, Parenting, and Child Development. Mahwah: Lawrence Erlbaum Associates.

Dressler, Wolfgang U. 2005. Morphological typology and first language acquisition: Some mutual challenges. - Geert Booij, Emiliano Guevara, Angeliki Ralli, Salvatore Sgroi, Sergio Scalise (Eds.), Morphology and Linguistic Typology. Bologna: Università degli studi di Bologna, 7-20.

Dressler, Wolfgang U.; Merlini Barbaresi, Lavinia 1994. Morphopragmatics. Diminutives and Intensifiers in Italian, German, and Other Languages. Berlin: Mouton de Gruyter. https://doi.org/10.1515/9783110877052

Dressler, Wolfgang U.; Kilani-Schoch, Marianne; Klampfer, Sabine 2002. How does a child detect morphology? Evidence from production. - R. Harald Baayen, Robert Schreuder (Eds.), Morphological Structure in Language Processing. Trends in Linguistics. Studies and Monographs 151. Berlin: Mouton de Gruyter, 391-425. https:// doi.org/10.1515/9783110910186.391

Ferguson, Charles A. 1977. Baby talk as a simplified register. - Catherine E. Snow, Charles A. Ferguson (Eds.), Talking to Children: Language Input and Acquisition. Cambridge, UK: Cambridge University Press, 209-236.

Fufaeva, Irina 2017. Ekspressivnye diminutivy v uslovijax konkurencii s nejtral'nymi suščestvitel'nymi (na materiale russkogo jazyka) ['Expressive Diminutives in Competition with Neutral Nouns (Based on Russian)']. Dissertacija kandidata nauk. Moscow: RGGU (on the rights of a manuscript).

Gleason, Berko J.; Perlmann, Rivka; Ely, Richard; Evans, David W. 1990. The baby talk register: Parent's use of diminutives. - Jeffrey L. Sokolov, Catherine E. Snow (Eds.), 
Handbook of Research in Language Development using CHILDES. Hillsdale, NJ: Lawrence Erlbaum Associates, 50-70.

Haman, Ewa 2003. Early productivity in derivation. A case study of diminutives in the acquisition of Polish. - Psychology of Language and Communication, 7 (1), 37-56.

Kasik, Reet 2015. Sõnamoodustus ['Word Formation']. Eesti keele varamu I. Tartu: Tartu Ülikooli Kirjastus.

Kazakovskaya, Victoria V. 2017. Acquisition of nominal compounds in Russian. - Wolfgang U. Dressler, F. Nihan Ketrez, Marianne Kilani-Schoch (Eds.), Nominal Compound Acquisition. Language Acquisition and Language Disorders Series 61. Amsterdam: John Benjamins, 63-90. https://doi.org/10.1075/lald.61.o4kaz

Kazakovskaya, Victoria V. 2019. Child nominal derivation and parental input: Evidence from morphology-rich Russian. - International Journal of Cognitive Research in Science, Engineering and Education, 7 (1), 121-129. https://doi.org/10.5937/IJCRSEE1901121K

Kazakovskaya, Victoria V.; Voeikova, Maria D. 2021. Acquisition of derivational morphology in Russian. - Veronika Mattes, Sabine Sommer-Lolei, Katharina Korecky-Kröll, Wolfgang U. Dressler (Eds.), The Acquisition of Derivational Morphology: A Crosslinguistic Perspective. Language Acquisition and Language Disorders 66. Amsterdam: John Benjamins, 170-195. https://doi.org/10.1075/lald.66.o7kaz

Kempe, Vera; Brooks, Patricia; Mironova, Natalija; Fedorova, Olga 2003. Diminutivization supports gender acquisition in Russian children. - Journal of Child Language, 30 (2), 471-485. https://doi.org/10.1017/So305000903005580

MacWhinney, Brian 2000. The CHILDES Project: Tools for Analyzing Talk. Mahwah, NJ: Lawrence Erlbaum Associates.

Olmsted, Hugh 1994. Diminutive morphology of Russian children: A simplified subset of nominal declencion in language acquisition. - Alexander Lipson: In memoriam. Columbus, Ohio: Slavica Publishers Inc, 165-207.

Protassova, Ekaterina; Voeikova, Maria D. 2007. Diminutives in Russian at the early stages of acquisition. - Ineta Savickienè, Wolfgang U. Dressler (Eds.), The Acquisition of Diminutives: A Cross-Linguistic Perspective. Language Acquisition and Language Disorders 43. Amsterdam: John Benjamins. https://doi.org/10.1075/lald.43.03pro

Rowe, Meredith L. 2008. Child-directed speech: Relation to socioeconomic status, knowledge of child development and child vocabulary skill. - Journal of Child Language, 35 (1), 185-205. https://doi.org/10.1017/So305000907008343

Savickienè, Ineta; Dressler, Wolfgang U. (Eds.) 2007. The Acquisition of Diminutives: A Cross-Linguistic Perspective. Language Acquisition and Language Disorders 43. Amsterdam: John Benjamins. https://doi.org/10.1075/lald.43

Slobin, Dan I. 2006. Cross-linguistic comparative approaches to language acquisition. - Keith Brown (Ed.), Encyclopedia of Language and Linguistics. London, 299-301. https:// doi.org/10.1016/Bo-08-044854-2/04199-7

Švedova, Natalia J. (Ed.) 2005 [1980]. Russkaja grammatika. T. 1 ['Russian Grammar. Vol. 1']. Moscow: Nauka.

Tomasello, Michael 2003. Constructing a Language. A Usage-Based Theory of Language Acquisition. Cambridge, MA - London: Harvard University Press.

Voeikova, Maria D. 2020. Strukturnye funkcii diminutivov v sovremennom russkom jazyke i produktivnost' ix upotreblenja [Structural functions of diminutives and their productivity in modern Russian]. - Voprosy jazykoznanija, 5, 38-56. https://doi. org/10.31857/0373-658X.2020.5.38-56 


\title{
DEMINUTIVIDE OMANDAMINE TÜPOLOOGILISELT ERINEVATES KEELTES EESTI JA VENE KEELE NÄITEL
}

\author{
Victoria V. Kazakovskaya ${ }^{1}$, Reili Argus ${ }^{2}$ \\ Vene Teaduste Akadeemia', Tallinna Ülikool²
}

Eesti ja vene keele deminutiivide varase omandamise võrdlev uurimus põhineb ükskeelsete laste pikiuuringu andmetel laste vanusest 1;3-3;1. Eesti ja vene keele deminutiivide puhul on tegemist kahe üsna erineva süsteemiga: kui vene keeles on deminutiivliiteid rohkesti ning deminutiive kasutatakse sageli, piirdub eesti keele deminutiivtuletus kolme liitega ning deminutiivide kasutus üldkeeles ei ole kuigi sage.

Uurimuses on deminutiivtuletust vaadeldud üldiselt tuletuse arenemise taustal ning jälgitud lähemalt produktiivsuse, läbipaistvuse, sisendkeele sageduse ja eri semantiliste kategooriate mõju omandamisele. Kõige tugevam mõju deminutiivide omandamisele paistab olema (nii sõnamoodustuslikul kui ka muutemorfoloogilisel) produktiivsusel: deminutiivtuletisi on laste varastes sõnaperedes ning ka varastes muuteminiparadigmades. Võib öelda, et rikka deminutiivtuletistega keeles (vene) omandatakse deminutiivid samal ajal kui vaese deminutiivtuletiste hulgaga keeles (eesti keel). Deminutiivid on eesti tuletussüsteemi omandamise algfaasis laste kõnes aga ainuke produktiivselt kasutatud tuletiste liik, kusjuures vene keeles toimub deminutiivide omandamine kogu vaatlusperioodi jooksul paralleelselt teiste tuletusliidete omandamisega. Kui eesti keeles deminutiivide hulk nii laste kui ka vanemate kõnes laste vanuse kasvades pigem kahaneb, siis vene keeles nende hulk stabiilselt kasvab.

Võtmesõnad: tuletus, deminutiivtuletus, esimese keele omandamine, lastekeel, lastele suunatud kõne, eesti keel, vene keel

Victoria V. Kazakovskaya is a leading researcher at the Department of Theoretical Grammar at the Institute for Linguistic Studies (Russian Academy of Sciences). Her research interests include philology, linguistics, first language acquisition.

Tuchkov per. 9, 199053 St. Petersburg, Russia

victory805@mail.ru

Reili Argus (Tallinn University) research interests are connected mainly with first language acquisition, with acquisition of morphology, word-formation, aspectuality, modality and evidentiality. Narva mnt 25, 10120 Tallinn, Estonia

reili.argus@tlu.ee 